\title{
Fanconi Anemia: main oral manifestations
}

\author{
Anemia de Fanconi: principais manifestações bucais
}

\author{
Anna Clara Duszczak D'AGULHAM ${ }^{1}$ \\ Cassiano Lima CHAIBEN ${ }^{1}$ \\ Antônio Adilson Soares de LIMA ${ }^{1}$ \\ Cassius Carvalho TORRES-PEREIRA ${ }^{1}$ \\ Maria Ângela Naval MACHADO ${ }^{1}$
}

\begin{abstract}
Fanconi Anemia is a recessive and rare genetic disorder, characterized by chromosomal instability that induces congenital alterations in individuals. Aplastic anemia due to the progressive failure of the bone marrow, malignant neoplasias such as acute myeloid leukemia, liver tumors and squamous cell carcinoma are some of the possible evolutions of Fanconi Anemia. Some of these diseases develop mainly after bone marrow transplantation. The aim of this critical review of the literature was to discourse about the main oral manifestations and their involvement in the health of individuals who are ill with Fanconi Anemia. The clinical oral findings described in the literature include periodontal changes, such as gingivitis and aggressive periodontitis, recurrent aphthous ulcers and traumatic lesions. Papillary atrophy, macroglossia, melanic pigmentation and squamous cell carcinoma are the most common oral manifestations on the tongue. An increased risk for the development of malignant neoplasias in individuals with Fanconi Anemia has been reported, and this is progressive after bone marrow transplantation. In radiographs, dental anomalies such as the presence of supernumerary teeth, tooth agenesis, tooth rotation and transposition of teeth are observed. Salivary flow and some salivary components are also altered. Due to the increased susceptibility to the development of cancer in this specific population, it is important for the dentist to know the common oral manifestations and potentially cancerous lesions, in order to make an early diagnosis in individuals with Fanconi Anemia.
\end{abstract}

Indexing terms: Bone marrow transplant. Fanconi Anemia. Oral manifestations. Oral mucosa. Squamous cell carcinoma.

\section{RESUMO}

A Anemia de Fanconi é uma desordem genética recessiva e rara caracterizada por uma instabilidade cromossômica que induz a alterações congênitas nos indivíduos. Anemia aplásica pela falência progressiva da medula óssea, neoplasias malignas como leucemia mielóide aguda, tumores de fígado e carcinoma espinocelular, são algumas das possíveis evoluções da Anemia de Fanconi. Algumas dessas doenças desenvolvem-se principalmente após o transplante de medula óssea. O objetivo desta revisão crítica da literatura é discorrer sobre as principais manifestações bucais e sua implicação na saúde dos indivíduos doentes da Anemia de Fanconi. Os achados clínicos bucais descritos na literatura incluem alterações periodontais, como gengivite e periodontite agressiva; úlcera aftosa recorrente e lesão traumática. A atrofia papilar, macroglossia, pigmentação melânica e o carcinoma espinocelular são as manifestações bucais mais comuns na língua. Um aumento do risco ao desenvolvimento de neoplasias malignas em indivíduos com Anemia de Fanconi é relatado, sendo este progressivo após o transplante de medula óssea. Nas radiografias são observadas anomalias dentárias como a presença de supranumerários, agenesias dentárias, giroversão e transposição dentária. O fluxo salivar e alguns componentes salivares também estão alterados. Devido à suscetibilidade aumentada ao desenvolvimento do câncer nessa população específica, torna-se importante para o cirurgião dentista conhecer as manifestações bucais comuns e as lesões cancerizáveis para realizar um diagnóstico precoce nos indivíduos com Anemia de Fanconi.

Termos de indexação: Transplante de medula óssea. Anemia de Fanconi. Manifestações bucais. Mucosa bucal. Carcinoma de células escamosas.

\section{INTRODUCTION}

Fanconi Anemia (FA) is a recessive genetic disorder, in which individuals present congenital alterations associated with consanguinity. It was described for the first time by Fanconi in 1927, in a case report of three brothers with a condition of progressive anemia, pancytopenia, physical anomalies and hyperpigmentation of the skin ${ }^{1}$.
This disease is characterized by the malfunctioning of the DNA repair mechanism, which present an increase in the rate of spontaneous damage, among these spontaneous chromosomal instability, and hypersensitivity of cells to the chromosomal breaking effect induced by clastogenic agents ${ }^{2-3}$.

Systemic changes begin in the first decade of life, and include hyperpigmentation of skin color (Café au lait

\footnotetext{
${ }^{1}$ Universidade Federal do Paraná, Curso de Odontologia, Departamento de Estomatologia. Av. Pref. Lothário Meissner, 632, Jardim Botânico, 80210-170, Curitiba, PR, Brasil. Correspondência para / Correspondence to: MAN MACHADO.E-mail: <man.machado@ufpr.br>
} 
spots);cardiac malformations; cardiac, gastrointestinal and renal alterations; skeletal alterations (low stature, anomalies of the thumb and radial bone, microcephaly, and mandibular anomalies); strabism, deafness and epicanthal fold ${ }^{4-5}$. In addition, there may be progressive pancytopenia, anemia, thrombocytopenia, leukopenia, macrocytosis and fetal erythropoiesis.

The mean age for diagnosis is 7 years, and the life expectancy is 25 years, and may attain between 30-40 years of age ${ }^{3}$.

Studies on the frequency of FA in the world are scarce. Recent studies have demonstrated a mean frequency of 1:181 individuals with Fanconi Anemia in the
United States of America. The estimate in 2010 was 550 to 975 individuals with FA living in the United States, and that 31 children per year are born with Fanconi Anemia, in this country $^{6}$. In Brazil, there are no studies that demonstrate the prevalence of frequency of Fanconi Anemia.

The study of the most prevalent oral manifestations in individuals with Fanconi Anemia is extremely important so that the dentist may make a correct early diagnosis and treatment of these alterations. In the literature, there are few reports of oral manifestations in individuals with Fanconi Anemia. The main manifestations related in individuals with Fanconi Anemia are represented as follows.

Chart 1. Main manifestations related in individuals with Fanconi anemia and authors.

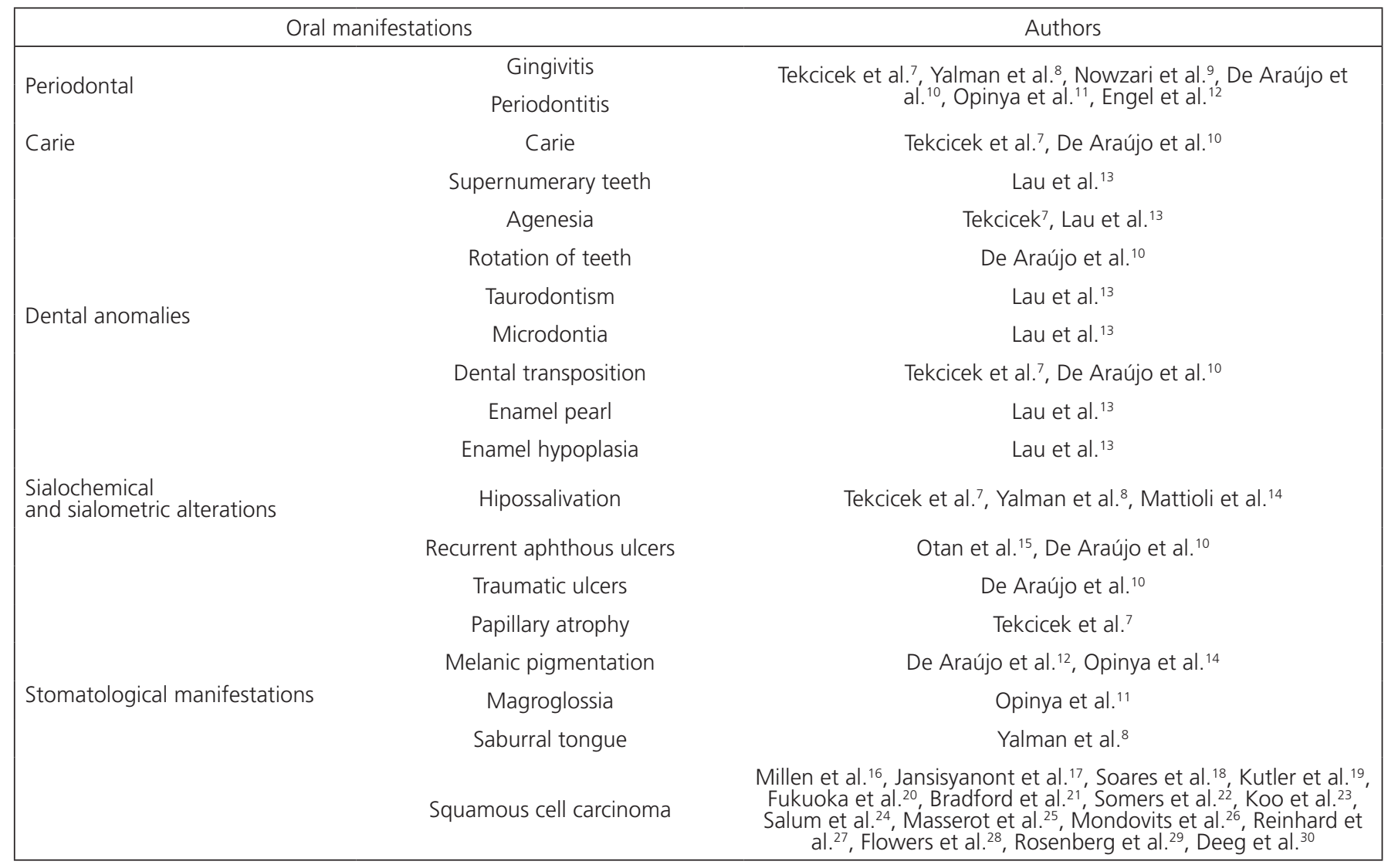

With a view to providing multidisciplinary care, prevention of oral alterations and development of squamous cell carcinoma, the aim of this review is to discourse about the main oral manifestations and their involvement in the health of patients with FA.

\section{Evolution of Fanconi Anemia}

The evolution of Fanconi Anemia may include aplastic anemia by the progressive failure of the bone marrow, malignant neoplasias, such as acute myeloid leukemia (AML), liver tumors and squamous cell carcinoma (SCC), which commonly affect the oral region, oropharynx and anogenital region ${ }^{31-32}$.

The goal of Fanconi Anemia treatment is to increase the survival of individuals, and establish a better quality of life. The aim is to control physical alterations (bifid thumbs, absence of radial bone, congenital dysplasia of the hip, scoliosis and syndactyly), re-establish the 
hematological condition (medullary aplasia) and treat the malignant alterations that develop in this population ${ }^{10}$.

In the treatment of medullary aplasia, the most severe adverse event in these individuals, this may be controlled by means of Androgen replacement therapy (ART), synthetic growth factors, bone marrow transplant (BMT) and gene therapy9.

Bone marrow transplantation is a good treatment alternative for the correction of hematological alterations in Fanconi Anemia ${ }^{33}$. Bone marrow transplantation eliminates the initial risk of death from hematopoietic insufficiency. On the other hand, it increases the risk for the development of neoplasias, as the transplanted stem cells do not eliminate the risk of residual leukemia, since some of the host cells with Fanconi Anemia may persist and maintain the risk of malignant transformation ${ }^{34}$.

During BMT, individuals with Fanconi Anemia undergo therapy with immunosuppressant medication and total body irradiation. These procedures associated with myelosuppression and complications arising from post-BMT, such as graft-versus-host disease (GVHD) and infections, are factors that significantly elevate the risk for development of neoplasias, mainly squamous cell carcinoma in the region of the head and neck ${ }^{4,34}$.

Systemic alterations such as high susceptibility for the development of neoplasias associated with altered hematological, endocrine and renal functions will reflect directly on the oral condition in patients with $A F$, which we shall describe as follows.

\section{Periodontal manifestation}

Gingivitis and periodontitis are the most cited oral manifestations in individuals with $A F^{12}$. Gingival bleeding and hyperemia are remarkable findings in patients with AF (Figure 1). Poor oral hygiene is added to the systemic condition that makes it an aggravating agent of gingivitis and periodontitis in these individuals 7,9 .

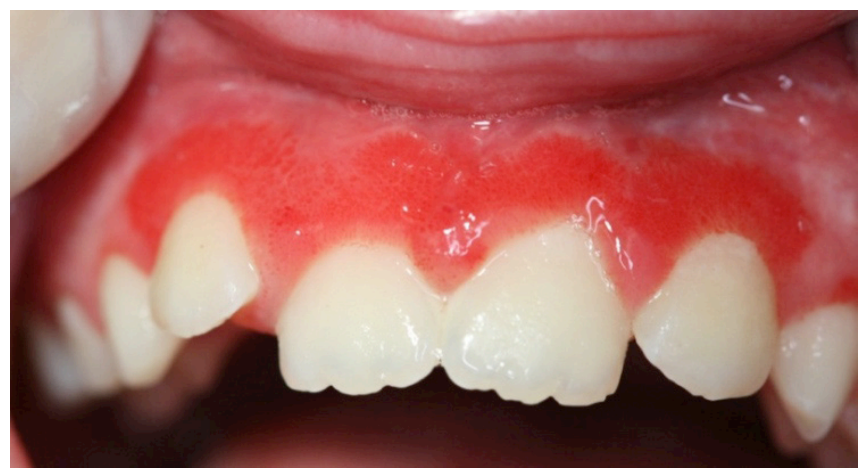

Figure 1. Gingivitis in a child with Fanconi Anemia after hematopoietic stem cell transplant.
It is important to remember that biofilm is the etiologic agent of gingivitis and gingival bleeding is one of the main clinical signs of this inflammation. Therefore, thrombocytopenia acts as a modifying agent of the systemic condition, and we suggest that this exacerbates gingival bleeding in these individuals. Another common hematological alteration in individuals with FA is chronic anemia, of which the main oral clinical characteristics are pallor of the mucosa and gingiva ${ }^{35}$.

On the other hand, De Araújo et al. ${ }^{10}$ considered that the hematological condition did not interfere in the presence or absence of periodontal disease, because they did not find a direct relationship between the platelet count in individuals with gingival inflammation and the periodontal health of individuals with AF. However, this same study demonstrated that $68.75 \%$ of the individuals with precarious oral hygiene presented gingival inflammation.

The aggressive periodontitis prevalent in youngsters, has also been described in individuals with $A F^{11-12}$. Accentuated horizontal loss of alveolar bone results from precarious oral hygiene, associated with leukocytic deficiency and the presence of microorganisms. Nowzari et al. ${ }^{9}$, reported the presence of Aggregatibacter actinomycetemcomitans, essential for the establishment of aggressive periodontitis and of human cytomegalovirus, associated with aggressive periodontal disease, presenting high pathogenicity in immunosuppressed individuals.

Furthermore, individuals with FA who received BMT, presented a deficiency in immune response, due to the use of immunosuppressant medications, increasing their susceptibility to periodontal infection, particularly aggressive periodontitis. However, Yalman et al. ${ }^{8}$, demonstrated that the plaque index, gingival index, periodontal probing depth and bleeding on probing values are significantly higher in individuals that did not receive BMT. For these authors, this is due to the greater attention paid to dental care in these individuals, particularly after BMT.

\section{Caries}

There are few reports in the literature, about the prevalence of caries in this population. Tekcicek et al. ${ }^{7}$ reported a prevalence of $35 \%$. However, the oral microbiota of these individuals does not appear to present alteration in comparison with individuals without hematological complications. Caries is associated with the accumulation of biofilm and precarious oral hygiene ${ }^{10,35}$. 
This may be explained by the health care being focused on systemic alterations and not on the oral condition, such as control of diet and oral hygiene.

The continuous and daily consumption of sucrose, presence of specific cariogenic microbiota, low socioeconomic condition and reduced access to dental care are relevant factors for the development of caries, a multifactorial disease ${ }^{36}$. The use of fluoride may be of great help in the control of dental caries ${ }^{37}$.

\section{Dental anomalies}

In radiographic studies, diverse dental anomalies have been observed in this population. With regard to number, agenesia and supernumerary teeth are the most common anomalies. The tooth with the highest prevalence of agenesia is the maxillary central incisor. With respect to position, rotation of permanent teeth and tooth transposition are the most reported anomalies ${ }^{10}$. The permanent canine is the tooth with the highest prevalence of transposition?

Curved, tapered roots with apical dilacerations, enamel pearl, taurodontia, microdontia, and enamel hypoplasia are the alterations in shape, dimension and dental structure described in these patients ${ }^{13}$.

Alterations in calcium metabolism during odontogenesis related to Vitamin D resistant rickets, explain some of the dental alterations in individuals with FA, such as agenesia and presence of supernumerary teeth ${ }^{13}$. The other alterations may be justified by the cranio-facial anomalies such as microcephaly and retro/micrognathia ${ }^{38}$.

Discrepancy between dental, chronological and bone age in individuals with FA is relevant, since the dental and bone age are lower than the chronological age ${ }^{39}$. Furthermore, it is common for these patients to present low stature, growth hormone deficiency and hypothyroidism. This may occur due to hypoactivity of the hypothalamus causing insufficiency of growth hormone, resistance to its action and hypothyroidism ${ }^{38}$.

\section{Sialochemical and sialometric alterations}

Reduction in salivary flow (hyposalivation) is an important oral manifestation in individuals with $\mathrm{FA}^{7,14}$. This occurs both in patients submitted to BMT, and in those who did not undergo transplantation ${ }^{8}$. However, there is not report of dry mouth sensation (xerostomia) or apparent clinical sign.

This diminished salivary flow may be justified by the pathogenesis of FA, related to endocrine alterations and or those of the central nervous system and due to the use of drugs, particularly on the central action ${ }^{40}$.
Alterations in urea and calcium concentrations in saliva have also been reported in individuals with FA, while amylase and total proteins have shown no alteration ${ }^{14}$.

Changes in salivary flow may lead to increase in the prevalence of caries, and increased predisposition to development of infections, however, this is not an isolated factor $r^{7,14}$.

In spite of these individuals presenting a low level of salivary flow, and high indices of urea and calcium in saliva being expected, these present reduced values when compared with individuals without systemic alterations ${ }^{14}$. This may be justified by dysfunction in calcium and urea absorption by the body. This applies to calcium by the gastrointestinal atresia, and urea by the renal and hepatic alterations ${ }^{14}$.

\section{Stomatological manifestations}

\section{Recurrent aphthous ulcer}

Recurrent aphthous ulcers are the most common lesions in soft tissues in individuals with $\mathrm{FA}^{15}$. As they present a painful symptomatology, these lesions are responsible for the increase in the frequency of these patients visiting the dental office (Figure 2).

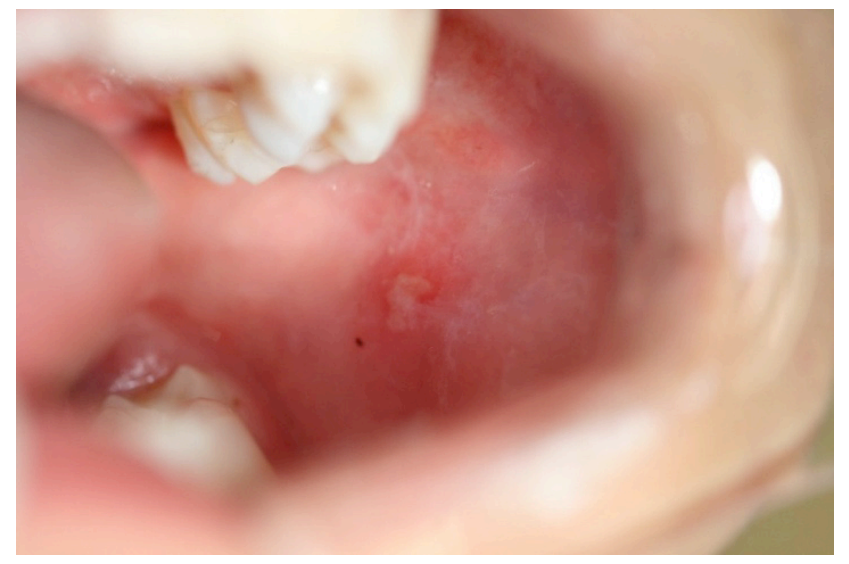

Figure 2. Recurrent ulcer in an individual with Fanconi Anemia.

Otan et al. ${ }^{15}$ associated recurrent aphthous ulcers with the hematological condition, particularly neutropenia and anemia, because there is an improvement in the condition of recurrent ulcers in the weeks after blood transfusions. Another justification found is leukocytic deficiency, reducing the immunity of these individuals, leading to greater facility for the development of these ulcerated lesions.

Traumatic non ulcerated lesions and petechiae are common in these individuals, and are normally related to low platelet counts ${ }^{10}$. 


\section{Tongue lesions}

There are many alterations in the tongue of individuals with FA. The most frequently described are: papillary atrophy ${ }^{7}$, saburral tongue ${ }^{8}$, macroglossia ${ }^{11}$ and melanic pigmentation, which may extend up to the floor of the mouth and gingivae ${ }^{10-11}$. Furthermore, the lesions and conditions with potential to become malignant, such as leukoplasias, erythroplasias, lichen planus, and squamous cell carcinoma itself must be considered important alterations in the tongue in individuals with $\mathrm{FA}$, particularly post-BMTO, because this is the site of preference for these alterations, with a prevalence of $69 \%{ }^{19}$. The alveolar ridge, retromolar trigone region, floor of the mouth, oral mucosa and gingivae are the areas of the major establishment of squamous cell carcinoma ${ }^{20-25}$.

Squamous cell carcinoma occurs with greater frequency in the region of the head and neck, particularly after bone marrow transplantation ${ }^{17-18}$, with the tongue being the site of preference. In general, the age for the development of neoplasias in patients with FA is significantly lower than the age at which these same alterations manifest themselves in the population in general ${ }^{14}$. In the head and neck region, the mean age for the appearance of tumors in the general population is around 45 years, while in individuals with $F A$, the age is 32 years $^{19}$.

Reports of SCC in children ${ }^{18-24}$, adolescents ${ }^{16,26-27}$, and young adult ${ }^{17-28}$, individuals with FA suggest genetic alterations in these individuals as the etiological factor of SCC of the tongue.

As from the time when BMT is performed, chromosomal instability is added to the clastgeogenic action of ionizing radiation before BMT, graft-versus-host disease (GVHD), immunosuppressant treatment and postBMT control therapy. All these factors together elevate the risk for the development of SCC by 4.4 times, in individuals with FA who have BMT performed ${ }^{29-30}$.

Not only does BMT act as an important predisposing factor, but external factors such as solar irradiation, smoking, alcoholism and human papillomavirus (HPV) confer an even greater risk for the development of malignant neoplasias ${ }^{16,34}$. Kutler et al. ${ }^{19}$ suggested that the carcinogenesis induced by HPV in individuals with FA is associated with the inactivation of $\mathrm{p} 53$ by HPV, and not by direct mutagenesis.

The treatment for SCC of the tongue is radical surgical removal of the tumor, associated with either radiotherapy and chemotherapy, or not. In this case, however, the prognosis is poor, and the recurrence free survival rate of 2 years is lower than $50 \%$. This occurs due to the low tolerance of individuals with FA to chemotherapy and radiotherapy, due to the defective DNA repair mechanism ${ }^{19}$.

Moreover, this tumor is particularly aggressive and has a high rate of recurrence. The survival rate on an average, is 6 months after diagnosis ${ }^{25}$.

\section{FINAL CONSIDERATIONS}

Knowledge of the oral manifestations and their treatment is of extreme relevance for the attention to and health care of individual with FA.

It is notable that patients with FA develop the same manifestations as those who do not present the disease. However, due to the hematological and endocrinal conditions, and mainly the chromosomal instability involved in this disease, these patients need differentiated care.

Periodontal disease, caries lesions and soft tissue, as well as dental alterations such as agenesias and supernumerary teeth, are the most common oral manifestations in this population.

The dentist, as a member of the multidisciplinary team that follows-up these patients, must know about the diverse aspects involved in its physiopathology and its repercussion on the mouth.

Monitoring the conditions and lesions with the potential to become cancerous, and their early diagnosis appears to be the best prognostic factor in individuals with FA, with regard to SCC. Careful examination of the mucosal tissues must regularly be performed, also in young individuals. Early diagnosis and prospective evaluation of patients may contribute to a better analysis of the development of SCC.

Routine dental exams guarantee the patient's motivation for re-establishment and maintenance of periodontal health, reduction in the incidence of caries and monitoring the oral health of these individuals.

\section{Collaborators}

ACD D'AGULHAM and CL CHAIBEN were responsible for the bibliographic survey, compilation of ideas and writing the article. AAS LIMA and CC TORRES-PEREIRA contributed additional information and the authors' experience in the care of individuals with Fanconi Anemia, and participated in writing the article. MAN MACHADO guided the research and participated in writing the article. 


\section{REFERENCES}

1. Pasquini $R$, Neto JZ, Medeiros CR, Bitencourt MA, Bonfim CMS, Moreira VA, et al. Carcinoma de células escamosas em língua pós-transplante de medula óssea por Anemia de Fanconi. Rev Bras Hematol Hemoter. 2003;25(4):239-46. doi: 10.1590/ S1516-84842003000400010

2. Auerbach $A D$. Fanconi anemia diagnosis and the diepoxybutane (DEB) test. Exp Hematol. 1993;21:731-3. doi: 10.1016/j. mrfmmm.2009.01.013

3. Alter BP. Fanconi's anemia, transplantation, and cancer. Pediatr Transplant. 2005;9(7):81-6. doi: 10.1111/j.13993046.2005.00440.x

4. Alter BP. Cancer in Fanconi anemia, 1927-2001. Cancer. 2003;97(2):425-40. doi: 10.1002/cncr.11046

5. D'Andrea AD, Grompe M. Molecular biology of Fanconi anemia: implications for diagnosis and therapy. Blood.1997;90(5):1725-36.

6. Rosenberg PS, Tamary H, Alter BP. How high are carrier frequencies of rare recessive syndromes? contemporary estimates for Fanconi Anemia in the United States and Israel. Am J Med Genet A. 2011;155A(8):1877-83. doi: 10.1002/ ajmg.a.34087.

7. Tekcicek M, Tavil B, Cakar, A, Pinar A, Unal S, Gumruk F. Oral and dental findings in children with Fanconi anemia. Pediatr Dent. 2007;29(3):248-52

8. Yalman N, Sepet E, Aren G, Mete Z, Külekçi G, Anak S. The effect of bone marrow transplantation on systemic and oral health in Fanconi's aplastic anemia. J Clin Pediatr Dent. 2001;25(4):329-32.

9. Nowzari $H$, Jorgensen MG, Ta TT, Contreras A, Slots J. Aggressive periodontitis associated with Fanconi's anemia: a case report. J Periodontol. 2001;72(11):1601-6. doi:10.1902/ jop.2001.72.11.1601

10. De Araújo MR, De Oliveira Ribas M, Koubik AC, Mattioli T, De Lima A.A, França BH. Fanconi's anemia: clinical and radiographic oral manifestations. Oral Dis. 2007;13(3):291-5. doi: 10.1111/j.1601-0825.2006.01282.x

11. Opinya GN, Kaimenyi JT, Meme JS. Oral findings in Fanconi's anemia: a case report. J Periodontol. 1988;59(7):461-3.

12. Engel JD, Ruskin JD, Harold K. Hematologic management of a patient with Fanconi's anemia undergoing bone grafting and implant surgery. J Oral Maxillofac Surg. 1992;50(3):288-92. doi: 10.1016/0278-2391(92)90329-X

13. Lau KK, Bedi R, O'Odonnell D. A case of Fanconi syndrome with associated hypodontia. Br. Dent. J. 1988;165(8):292-4.

14. Mattioli TM, Koubik AC, de Oliveira Ribas MO, França BHS, Brancher JA, de Lima AAS. Salivary flow rate, calcium, urea, total protein, and amylase levels in Fanconi Anemia. J Pediatr Hematol Oncol. 2010;32(2):46-9. doi: 10.1097/ MPH.0b013e3181c29c11

15. Otan F, Açikgöz G, Sakallioglu U, Ozkan B. Recurrent aphthous ulcers in Fanconi's anaemia: a case report. Int J Paediatr Dent. 2004;14(3):214-7. doi: 10.1111/j.1365-263X.2004.00549.x
16. Millen FJ, Rainey MG, Hows JM, Burton PA, Irvine GH, Swirsky D. Oral squamous cell carcinoma after allogeneic bone marrow transplantation for Fanconi anaemia. $\mathrm{Br} J$ Haematol. 1997;99(2):410-4

17. Jansisyanont $P$, Pazoki $A$, Ord RA. Squamous cell carcinoma of the tongue after bone marrow transplantation in a patient with Fanconi's anemia. J Oral Maxillofac Surg. 2000;58(12):1454-7. DOI: 10.1053/joms.2000.19212

18. Soares MF, Machuca TN, Benites RPF, Wal R, Araki R, Crespo G, et al Early presentation of squamous cell carcinoma after bone marrow transplantation in a boy with Fanconi anemia. J Bras Patol Med Lab. 2004;40(4):276-9. doi: 10.1590/S1676-24442004000400011

19. Kutler DI, Singh B, Satagopan J, Batish SD, Berwick $M$, Giampietro PF, et al. A 20-year perspective on the International Fanconi Anemia Registry (IFAR). Blood. 2003;101(4):1249-56.

20. Fukuoka K, Nishikawa K, Mizumoto Y, Shimoyama T, Mikasa $K$, Kounoike $Y$, et al. Fanconi's anemia with squamous cell carcinoma: a case report and a review of literature. Rinsho Ketsueki. 1989;30(11):1992-6.

21. Bradford CR, Hoffman HT, Wolf GT, Carey TE, Baker SR, McClatchey KD. Squamous carcinoma of the head and neck in organ transplant recipients: possible role of oncogenic viruses. Laryngoscope. 1990;100(2 pt 1):190-4. doi: 10.1288/00005537$199002000-00016$

22. Somers GR, Tabrizi SN, Tiedemann K, Chow CW, Garland SM, Venter DJ. Squamous cell carcinoma of the tongue in a child with Fanconi anemia: a case report and review of the literature. Pediatr Pathol Lab Med. 1995;15(4):597-607.

23. Koo WH, Knight LA, Ang PT. Fanconi's anaemia and recurrent squamous cell carcinoma of the oral cavity: a case report. Ann Acad Med Singapore. 1996;25(2):289-92.

24. Salum FG, Martins GB, de Figueiredo MA, Cherubini K, Yurgel LS, Torres-Pereira C. Squamous cell carcinoma of the tongue after bone marrow transplantation in a patient with Fanconi anemia. Braz Dent J. 2006;17(2):161-5. doi: 10.1590/S010364402006000200015

25. Masserot C, Peffault de Latour R, Rocha $V$, Leblanc T, Rigolet $A$, Pascal $F$, et al. Head and neck squamous cell carcinoma in 13 patients with Fanconi anemia after hematopoietic stem cell transplantation. Cancer. 2008;15;113(12):3315-22. doi: 10.1002/cncr.23954

26. Mondovits B, Vermylen C, Brichard B, Cornu G. Bone marrow transplantation in Fanconi's anemia: about seven cases. Arch Pediatr. 2001;8(8):801-6. doi: 10.1016/S0929-693X(01)00538-3

27. Reinhard H, Peters I, Gottschling S, Ebell W, Graf N. Squamous cell carcinoma of the tongue in a 13-year-old girl with Fanconi anemia. J Pediatr Hematol Oncol. 2007;29(7):488-91.

28. Flowers MED, Doney KC, Storb R, Deeg HJ, Sanders JE, Sullivan $\mathrm{KM}$, et al. Marrow transplantation for Fanconi anemia with or without leukemic transformation: an update of the Seattle experience. Bone Marrow Transplant. 1992;9(3):167-73.

29. Rosenberg PS, Socié G, Alter BP, Gluckman E. Risk of head and neck squamous cell cancer and death in patients with Fanconi anemia who did and did not receive transplants. Blood. 2005;105(1):67-73. 
30. Deeg HJ, Socie G, Schoch G, Henry-Amar M, Witherspoon RP, Devergie $A$, et al. Malignancies after marrow transplantation for aplastic anemia and fanconi anemia: a joint seattle and paris analysis of results in 700 patients. Blood. 1996;87(1):386-92.

31. Altay C, Alikaşifoglu M, Kara A, Tunçbilek E, Ozbek N, SchroederKurth TM. Analysis of 65 Turkish patients with congenital aplastic anemia(Fanconi anemia and non-Fanconi anemia): Hacettepe experience. Clin Genet. 1997;51(5):296-302.

32. Oksüzoğlu B, Yalçin S. Squamous cell carcinoma of the tongue in a patient with Fanconi's anemia: a case report and review of the literature. Ann Hematol. 2002;81(5):294-8.

33. Zanis-Neto J, Ribeiro RC, Medeiros C, Andrade RJ, Ogasawara $V$, Hüsh $\mathrm{M}$, et al. Bone marrow transplantation for patients with Fanconi anemia: a study of 24 cases from a single institution. Bone Marrow Transplant. 1995;15(2):293-8.

34. Socié G, Scieux C, Gluckman E, Soussi T, Clavel C, Saulnier P, et al. Squamous cell carcinomas after allogeneic bone marrow transplantation for aplastic anemia: further evidence of a multistep process. Transplantation. 1998;66(5):667-70.

35. Açikgöz A, Ozden FO, Fisgin T, Açikgöz G, Duru F, Yarali N, et al. Oral and dental findings in Fanconi's anemia. Pediatr Hematol Oncol. 2005;22(6):531-9. doi: 10.1080/08880010591002413
36. Freire MCM, Batista SMO. Prevalência de cárie e necessidade de tratamento em escolares de seis a doze anos da rede pública de ensino. Rev Saúde Pública. 1999;33(4):124-30. doi: 10.1590/ S0034-89101999000400010

37. Künzel W, Fisher T. Caries prevalence after cessation of water fluoridation in la Salud, Cuba. Caries Res. 2000;34(1):20-5.

38. Martins W, de Fátima L, Avila C, de Oliveira Ribas M, Cândido L, Ignácio SA, Bonfim CM. A Study of Facial Pattern in Patients With Fanconi's Anemia. Cleft Palate Craniofac J. 2014; 51(1):839. doi: 10.1597/11-321.1.

39. Koubik AC, Franca BH, Ribas MO, de Araujo MR, Mattioli TM, de Lima AA. Comparative study of chronological, bone, and dental age in Fanconi's anemia. J Pediatr Hematol Oncol. 2006;28(4):260-2

40. Pankhurst $C L$, Smith EC, Rogers JO, Dunne SM, Jackson SH, Proctor G. Diagnosis and management of the dry mouth: Part 1. Dent Update. 1996;23(2):56-62.

Received on: 4/8/2012 Final version resubmitted on: 26/8/2013 Approved on: 6/12/2013 
